\title{
弯曲水路の河床変化について \\ VARIATION OF BED PROFILE WITH TIME IN CURVED OPEN CHANNEL
}

\author{
吉川秀 夫*·池田駿 介**・北 川 明*** \\ By Hideo KIKKAWA, Syunsuke IKEDA and Akira KITAGAWA
}

\section{1. 序論}

河川弯曲部は河道の弱点部であって, 洪水の流下に際 しては水衝部となり, 局所洗掘をひきおこし,さらには 河岸あるいは堤防の決壊にまで至る場合さえある。この ような洗掘は強力ならせん流によって弯曲部の外岸側に 生ずることが知られているが，この洗掘および堆積の機 構を解明することは堤防, 護岸, 取水口および橋脚など の河川構造物の設計をより合理的に行ううえで重要であ る. 一般に日本の河川は洪水の継続時間が短く, ある洪 水流量に対して河床が安定な横断形状に達する前に減水 してしまうことが多く,したがってこのような場合には 河床の時間的な変化, 特に堤防付近の洗掘深の変化を定 量的に把握し，予測することが必要である.

弯曲水路の河床変化に関寸る研究は野外観測に始ま り, 現在その洗掘と堆積の機構が次第に明らかにされつ つある.けれどもその研究の多くはある流量に対する安 定な横断形状に関するものであって, 河床形状の時間的

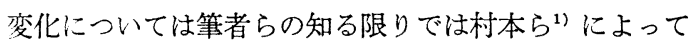
取り扱われたのみである，村本らは流砂の連続式，流砂 量式, 河床高と流れを関倸づる式, および Rozovskii によって得られた二次流の速度分布を河床付近で修正し た式を連立させて横断方向の河床変化を表わす式を導 き, 数值計算によって河床变化を求めている. しかし, 局所洗掘が進行するとともに横断方向の流砂量が減少す る機構を取り入れなかったために河床変化の初期の段階 のみしか取り扱らことができなかったと思われる.

本稿は横断河床形状が安定勾配に達するまでの全過程 を支配する力学的機構の解明と長期的な河床变化につい

* 正会員 工博 東京工業大学教授 工学部土木工学科

** 正会員 工博 埼玉大学講師 工学部建設基礎工学科

*** 正会員 工修 建設省士木研究所研究員河川部水文研究 室
て定量的に把握することを目的としたものであって，ま ず 2. では弯曲部の河床上を運動している砂粒子に働く カのつり合い式を主流方向および横断方向にそれぞれ立 て, 物理的な考察を加えることによって砂粒子の運動の 方向を表わす式を導き出し, さらに二次流の速度分布を 表わす式, 流砂の連続式, 流砂量式を連立させ, 時間的 な河床変化を表わす方程式を導き出す. また, この方程 式を無次元表示することによって, 弯曲部の河床変化を 支配している無次元量を明らかにする.

次に 3. では固定床と移動床での実験を行い，これら の結果について検討を加え, 主流の速度分布, 二次流の 速度分布, 河床上のせん断力分布, 洗掘と堆積の進行過 程, 最終的な状態での河床形状等を実験的に明らかにし あわせて計算值との比較, 検討を行う.

\section{2. 河床変化に関する考察と支配方程式の誘導}

弯曲部での横断方向の河床変化の特徴は強いらせん流 による外岸側から内岸側への流砂に伴う内岸での堆積, および外岸での洗掘の過程である. ある点の河床変化は 運び去られる流砂量と運びこまれる流砂量の差によって 決まってくるから，横断方向の流砂量をいかに見積るか が問題となる. 主流方向の流砂量は河床面でのせん断力 の大きさによって決定されると考えられるが, 横断方向 の流砂量は二次流によってせん断力の働く方向が内岸側 へずれることと横断方向の河床勾配によって決定される であろう. 河床が横断方向に水平である場合, すなわち 河床変化の初期の段階においては河床付近の流向と流砂 方向は一致しているが, 洗掘と堆積が進行し河床が次第 に横断方向に勾配を持つようになるにつれて重力の影響 を受け，河床付近の流向と流砂方向とは一致しなくな り，ずれが生じてくるものと考えられる. 横断方向に流 砂量がないこと,つまり砂粒子が弯曲水路と同じ曲率で 動くことが動的な安定勾配であることを考えると，安定 
勾配に達した時そのずれは最大になるものと考えられ る.このような安定勾配に至るまでの全過程における流 砂の挙動の把握が長期的な河床変化の力学的解明につな がるものと思われるので，ここでは以上の考察をもとに 流下方向に流れと河床が一様な場合の横断方向の河床変 化を表わす基礎式を導くことにする.

\section{（1）流砂の方向を表わす式の誘導}

図一1 に示されているような座標系において, 弯曲水 路床上を運動している 1 個の砂粒子に㗢く力を考え運動 方程式を立てる. 河床変動は砂粒子の運動と比較して極 めてゆるやかであるから, 砂粒子の運動は定常運動とし て取り扱うことができる.砂粒子は近似的に球とし, 回 転による Magnus 効果, Coriolis の力などは無視する. そうすると砂粒子に働く力は坑力, 揚力, 重力, 摩擦 力, 遠心力が考えられる. 図一1 を参照し, 摩擦力は砂 粒子の運動方向と逆向きに働き, 抗力は砂粒子付近の流 体と砂粒子との相対速度の方向に㗢くことを考慮に入れ ると， $\theta$ 方向および $R$ 方向の力のつり合い式はそれぞ れ次のようになる.

$\theta$ 方向 :

$$
\begin{aligned}
& \frac{\rho}{2} C_{D} \frac{\pi}{4} d^{2}\left|U-V_{s}\right|^{2} \frac{\left|U_{\theta}-V_{s \theta}\right|}{\left|U-V_{s}\right|} \\
& +\frac{\pi}{6} \cdot d^{3}\left(\rho_{s}-\rho\right) g \cdot i_{\theta}-\mu\left\{\frac{\pi}{6} d^{3}\left(\rho_{s}-\rho\right) g \frac{\partial R}{\partial S}\right. \\
& \left.\quad-\frac{\rho}{2} C_{L} \frac{\pi}{4} d^{2}\left|U-V_{s}\right|^{2}\right\} \cdot \frac{\left|V_{s \theta}\right|}{\left|V_{s}\right|}=0 \quad \cdots \cdots(1)
\end{aligned}
$$

$R$ 方向 :

$$
\begin{aligned}
& \frac{\rho}{2} C_{D} \frac{\pi}{4} d^{2}\left|U-V_{s}\right|^{2} \frac{\left|\hat{U}_{r}-\hat{V}_{s r}\right|}{\left|U-V_{s}\right|} \\
& \quad-\frac{\pi}{6} d^{3}\left(\rho_{s}-\rho\right) g \frac{\partial \eta}{\partial S}-\mu\left\{\frac{\pi}{6} d^{3}\left(\rho_{s}-\rho\right) g \frac{\partial R}{\partial S}\right. \\
& \left.\quad-\frac{\rho}{2} C_{L} \frac{\pi}{4} d^{2}\left|U-V_{s}\right|^{2}\right\} \cdot \frac{\left|\hat{V}_{s r}\right|}{\left|V_{s}\right|} \\
& -\rho_{s} \frac{\pi}{6} d^{3} \frac{\left|V_{s}\right|^{2}}{R_{s}}=0 \cdots \cdots \cdots \cdots \cdots \cdots \cdots \cdots \cdots(2)
\end{aligned}
$$

ここに, $\rho$ : 流体の密度, $\rho_{s}$ : 砂粒子の密度, $d$ : 砂粒 子の直径, $g$ : 重力の加速度, $C_{D}$ : 抗力係数, $C_{L}$ : 揚

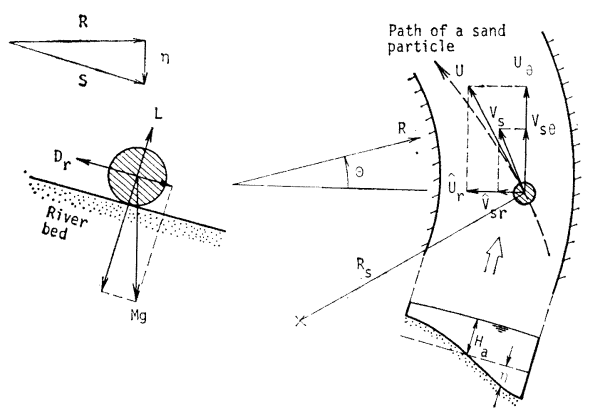

図-1 砂粒子に働くカの模式図
力係数, $\mu$ : 砂粒子と河床との動摩擦係数, $i_{\theta}: \Theta$ 方向 の河床勾配, $U$ : 砂粒子高さでの流体の速度ベクトル, $U_{\theta}, \hat{U}_{r}: U$ の $\Theta$ および $R$ 方向成分（“八” は内向き正 を示す), $V_{s}$ : 砂粒子の速度ベクトル, $V_{s \theta}, \hat{V}_{s r}: V_{s}$ の $\Theta$ および $R$ 方向成分である.

水深に比較して水路幅と曲率半径の大きな水路につい て考えると, 主流と比較して二次流は小さくなり,

$$
\frac{\left|V_{s \theta}\right|}{\left|V_{s}\right|} \fallingdotseq 1, \frac{\left|U_{\theta}-V_{s \theta}\right|}{\left|U-V_{s}\right|} \fallingdotseq 1
$$

となり，また一般に

$$
\mu \gg i_{\theta}, \frac{\partial R}{\partial S} \fallingdotseq 1
$$

であることを考慮に入れると，式 (1) より次の関係式在 得ることができる.

$$
\left|U-V_{s}\right|=\left\{\frac{4}{3} \frac{\mu g d\left(\rho_{s} / \rho-1\right)}{C_{D}+\mu C_{L}}\right\}^{1 / 2} \ldots
$$

式 (3) を式 (2) に代入して, $\left|\hat{V}_{s r}\right| /\left|V_{s}\right|$ について整理す ると次式が得られる.

$$
\begin{aligned}
\frac{\left|\hat{V}_{s r}\right|}{\left|V_{s}\right|}= & \frac{\left\{\frac{3}{4} \frac{\mu C_{D}}{1+\mu C_{L} / C_{D}}\right\}^{1 / 2} \frac{\left|\hat{U}_{r}\right|}{\left\{\left(\rho_{s} \mid \rho-1\right) g d\right\}^{1 / 2}}}{\left\{\frac{3}{4} \frac{\mu C_{D}}{1+\mu C_{L} / C_{D}}\right\}^{1 / 2} \frac{\left|V_{s}\right|}{\left\{\left(\rho_{s} / \rho-1\right) g d\right\}^{1 / 2}}} \\
& * \frac{-\frac{\partial \eta}{\partial S}-\frac{\left|V_{s}\right|^{2}}{\left(1-\rho / \rho_{s}\right) g R_{s}}}{\cdots} \ldots \ldots \ldots(4)
\end{aligned}
$$

ここで分子の第 2 項は先に仮定したように $\partial R / \partial S \fallingdotseq 1$ よ り

$$
\frac{\partial \eta}{\partial S} \fallingdotseq \frac{\partial \eta}{\partial R}
$$

とおくことができ，また砂粒子自身が運動することによ って生ずる遠心力を表わす第 3 項は本研究で行われた実 験の例でも他の項の高々 $1 \%$ 程度であり, 一般の河川で は曲率半径が非常に大きいことからさらに小さなオーダ 一となり，無視することができる. $U$ と $V_{s}$ の方向の ずれは, 二次流の大きさが主流の大きさと比較して小さ いことから無視することができ, 近似的に, $\left|U-V_{s}\right| \fallingdotseq$ $|U|-\left|V_{s}\right|$ とすることができる. よって式 (3) から, 式 (4) の分母の $\left|V_{s}\right|$ を消去すると, 式 (4) は結局

$$
\begin{aligned}
\frac{\left|\hat{V}_{s r}\right|}{\left|V_{s}\right|}= & \frac{\left|\hat{U}_{r}\right|}{|U|} \\
& -\frac{\frac{\partial \eta}{\partial R}}{\left\{\frac{3}{4} \frac{\mu C_{D}}{1+\mu C_{L} / C_{D}}\right\}^{1 / 2} \frac{|U|}{\left\{\left(\rho_{s} / \rho-1\right) g d\right\}^{1 / 2}}}
\end{aligned}
$$

となる. 式 (5) は砂粒子の運動方向を表わす式である が, 河床が横断方向に水平な河床变動の初期の段階, す なわち $\partial \eta / \partial R=0$ の場合には砂粒子の運動方向と砂粒子 付近の流れの方向は一致し, 横断安定河床形状に達した 状態, つまり砂粒子が弯曲水路の曲率と同じ曲率で動く 
ような状態, $\hat{V}_{s r}=0$ で式 (5) は

$$
\frac{d \eta}{d R}=\left\{\frac{3}{4} \frac{\mu C_{D}}{1+\mu C_{L} / C_{D}}\right\}^{1 / 2} \frac{\left|\hat{U}_{r}\right|}{\left\{\left(\frac{\rho}{\rho_{s}}-1\right) g d\right\}^{1 / 2}}
$$

となることを示している. 式 (6) は筆者の内の一人によ って得られた横断安定河床形を与える基礎方程式 ${ }^{2)}$ とま ったく一致しており, 式（5）の物理的妥当性を裏づけ ている. 以上の考察によって, 砂粒子の運動方向は河床 付近の流向とその点での横断河床勾配によって決定され ることが示された。

式 (5) によって砂粒子の運動方向を具体的に定めるに は河床付近での流速の大きさと二次流の大きさを知らね ばならない. 水路断面が長方形から大きくずれていない 場合について，側壁の影響が無視しうる所における二次 流の速度分布を表わす式が求められている2). この式の 特徴は, Rozovskii の式と異なって, 河床付近の速度を 有限な值として与えることができ, 河床付近の二次流の 大きさが重要となる弯曲水路床での砂の移動を取り扱う 場合に有効な点にある. この二次流の速度分布は次式で 示される.

$$
\frac{U_{r}}{U_{a}}=f^{2}\left(\frac{R}{R_{0}}\right) \frac{H}{R} \frac{1}{\kappa}\left\{F_{A}(\xi)-\frac{1}{\kappa} \frac{U_{* a}}{U_{a}} F_{B}(\xi)\right\}
$$

ここに

$$
\begin{aligned}
& F_{A}(\xi)=-15\left(\xi^{2} \log _{e} \xi-\frac{1}{2} \xi^{2}+\frac{15}{54}\right) \\
& F_{B}(\xi)=\frac{15}{2}\left(\xi^{2} \log ^{2} \xi-\xi^{2} \log \xi+\frac{1}{2} \xi^{2}-\frac{19}{54}\right) \\
& \xi=\frac{Z}{H}
\end{aligned}
$$

$U_{a}$ : 断面平均流速, $U_{* a}$ : 断面平均摩擦速度, $\kappa:$ カル マン定数, $Z$ : 垂直方向座標, $H$ : 水深, $f\left(R / R_{0}\right)$ : 横 断方向の主流の速度分布を表わし, 平均すれば 1 にな る. $R_{0}$ : 深さ方向の平均流速 $U_{m}$ が $U_{a}$ となる座標 $R$ の値である. 式 (7) は $U_{* a} / U_{a}$ の值によって変化する がその変化は小さい.

ここで簡単のために

$$
F(\xi)=F_{A}(\xi)-\frac{1}{\kappa} \frac{U_{* a}}{U_{a}} F_{B}(\xi)
$$

とおくと, 砂粒子高さにおける二次流の大きさは, $F_{A}$ $(\xi), F_{B}(\xi)$ の大きさが 河床のごく近傍ではほとんど変 化しないことから， $\xi=0$ での值

$$
\begin{aligned}
U_{r}(0) & =U_{a} f^{2}\left(\frac{R}{R_{0}}\right) \frac{H}{R} F(0) \\
& =U_{a} f^{2}\left(\frac{R}{R_{0}}\right) \frac{H}{R}\left(-4.167+2.640 \frac{1}{x} \frac{U_{* a}}{U_{a}}\right)
\end{aligned}
$$

を用いることができる．ただし $F_{A}(0)=-4.167, F_{B}$
(0) $=-2.640$ である.

次に砂粒子高さの主流の流れについては次のように考 えればよい. ここで取り扱っている流れは粗面上の流れ であるから速度分布は

$$
\frac{U_{\theta}}{U_{*}}=\frac{1}{\kappa} \log \frac{Z}{k_{s}}+A_{r}
$$

によって与えられる.

ここに, $U_{*}$ : 摩擦速度, $k_{s}$ : 相当粗度, $A_{r}$ : 積分定 数である. 一般に $k_{s}$ は, $k_{s} \simeq(0.5 \sim 4.0) d$ の範囲にあ ることが知られているが, ここでは $k_{s} \simeq d$ とする. そ うすると砂粒子の高さ $Z=d$ における主流の流速は

$$
U_{\theta}=U_{*} A_{r}
$$

となる.よって砂粒子高さ付近の流向は式 (8) と式 (10)によって，次式のように与えられる.

$$
\frac{\left|\hat{U}_{r}\right|}{|U|}=\frac{\left|\hat{U}_{r}\right|}{\left|U_{\theta}\right|}=-f^{2}\left(\frac{R}{R_{0}}\right) \frac{U_{a}}{A_{r} U_{*}} \cdot \frac{H}{R} \frac{1}{\pi} F(0)
$$

主流の横断方向の速度分布を表わす $f\left(R / R_{0}\right)$ は, 二 次流の完全発達域では水路の断面形が長方形よりずれた 場合においても, 強制渦型が成り立つことが確かめられ ている3). すなわち次のように書くことができる.

$$
f\left(\frac{R}{R_{0}}\right)=\frac{R}{R_{0}}
$$

横断方向に水深が変化する場合の河床せん断力あるい は摩擦速度の横断方向分布については次のように考え る. 横断方向のある点における深さ方向 の平均流速を $U_{m}$ とし, そこでの河床せん断力 $\tau$ が $U_{m}$ の二乗に比 例すると仮定すると, $\tau$ は次式のように表現される.

$$
\tau=\frac{\rho}{2} C_{f} U_{m}^{2}
$$

ここに, $C_{f}$ : 摩擦係数である. $C_{f}$ については直線水 路と同様に Manning の式が成り立つものとすれば次の ように与えられる.

$$
C_{f}=\frac{2 g n^{2}}{H^{1 / 3}}
$$

ここに, $n$ : Manning の粗度係数である. $U_{m}$ と断面内 の平均流速 $U_{a}$ との関係は, 横断方向に強制渦型の速 度分布が仮定されているから

$$
U_{m}=f\left(\frac{R}{R_{0}}\right) U_{a}=\frac{R}{R_{0}} U_{a}
$$

と書ける. 以上のことから河床におけるせん断力は次の ようになる。

$$
\tau=\rho g n^{2} H^{-1 / 3} f^{2}\left(\frac{R}{R_{0}}\right) U_{a^{2}}
$$

したがって摩擦速度は

$$
\begin{aligned}
U_{*} & =\sqrt{\frac{\tau}{\rho}}=g^{1 / 2} n H^{-1 / 6} f\left(\frac{R}{R_{0}}\right) U_{a} \\
& =H^{-1 / 6} H_{a}^{1 / 6} f\left(\frac{R}{R_{0}}\right) U_{* a} \ldots \ldots . .
\end{aligned}
$$


となる。

式（11）に式（14）を代入すると, 砂粒子高さでの流 向が得られて次のように書ける.

$$
\begin{gathered}
\frac{\left|\hat{U}_{r}\right|}{|U|}=-f\left(\frac{R}{R_{0}}\right) \frac{U_{a}}{A_{r} U_{* a}}\left(\frac{H}{H_{a}}\right)^{1 / 6} \frac{H}{R} \frac{1}{\kappa} \\
\cdot\left(-4.167 \div 2.640 \frac{1}{\kappa} \frac{U_{* a}}{U_{a}}\right)
\end{gathered}
$$

上式は側壁の影響を受けない水路中心付近で成り立つも のであり，内壁および外壁を横切る流れがないという物 理的な条件によって上式に次のような補正を行う.

$$
\frac{\left|\hat{U}_{r}\right|}{|U|}=-f_{0}\left(\frac{R}{R_{0}}\right) \frac{U_{a}}{A_{r} U_{* a}}\left(\frac{H}{H_{a}}\right)^{1 / 6} \frac{H}{R} \frac{1}{\kappa} F(0)
$$

ここに， $f_{0}$ : 側壁の近くでは次第に 0 に近づき，それ以 外の領域では $R / R_{0}$ となる関数である.

式 (5)，(10)，(14)，(15）によって, 砂粒子の運動方 向は最終的に次のように書くことができる。

$$
\begin{aligned}
\frac{\left|\hat{V}_{s r}\right|}{\left|V_{s}\right|}= & -f_{0}\left(\frac{R}{R_{0}}\right) \frac{U_{a}}{A_{r} U_{* a}}\left(\frac{H}{H_{a}}\right)^{1 / 6} \frac{H}{R} \frac{1}{\kappa} F(0) \\
& -\frac{\left(\frac{H}{H_{a}}\right)^{1 / 6} \frac{\partial \eta}{\partial R}}{\sqrt{\frac{3}{4} \frac{\mu C_{D}}{1+\mu C_{L} / C_{D}} \frac{A_{r} \frac{R}{R_{0}} \lambda_{0} U_{* a}}{\sqrt{\left(\rho_{s} / \rho-1\right) g d}}}}
\end{aligned}
$$

ここに，新しく導入された倸数 $\lambda_{0}$ は同じく表面に露出 している他の砂粒子によって遮蔽される効果の度合いで あり,一般に遮蔽係数とよばれている.岩垣 ${ }^{4}$ によればこ の効果は砂粒が全面的に運動している場合には，掃流力 $U_{* a}{ }^{2} /\left(\rho_{s} / \rho-1\right) g d$ を 0.35 倍にする働きがあるとして いる. ここでは $\lambda_{0}$ は $U_{* a} / \sqrt{\left(\rho_{s} / \rho-1\right) g d}$ に対して定 義されているので,

$$
\lambda_{0}=\sqrt{0.35} \fallingdotseq 0.592
$$

とする. 以上の考察から砂粒子の運動方向を決定するこ とができた。

\section{（2）河床変動を表わす基礎式}

先にも述べたようにある点の河床変化は流入してくる 流砂量と流出していく流砂量の差で決定される.この関 係を円筒座標系で主流方向に変化しない場合（すなわち $\partial / \partial \Theta=0)$ について書くと次式で表わされる.

$$
\frac{\partial \eta}{\partial t}-\frac{1}{1-\lambda} \frac{1}{R} \frac{\partial}{\partial R}\left(R q_{r}\right)=0 \text {. }
$$

ここに, $\lambda:$ 空偗率, $q_{r}: R$ 方向の単位幅当りの流砂量 である. $q_{r}$ は砂粒子の運動方向の流砂量 $q_{t}$ に $\left|\hat{V}_{s r}\right| /\left|V_{s}\right|$ を乗じて次のように表わされる。

$$
q_{r}=-\frac{\left|\hat{V}_{s r}\right|}{\left|V_{s}\right|} q_{t}
$$

ただし， $R$ の方向を正とする.ここで， $\Theta$ 方向の流砂
量を $q_{\theta}$ とすると $q_{\theta} \gg q_{r}$ であるから

$$
q_{t}=\left(q_{\theta}^{2}+q_{r}^{2}\right)^{1 / 2} \fallingdotseq q_{\theta}
$$

とすることができる.

$q_{\theta}$ を与える流砂量公式として佐藤-吉川-芦田公式 ${ }^{5)}$ 用いる.この式は計算や式の変形に際しては多少複雑で あるが, Manning の粗度係数 $n$ が与えられれば流砂量 が求まる便利さがある， $q_{\theta}$ は次式で与えられる.

$$
q_{t} \fallingdotseq q_{\theta}=\varphi \frac{U_{*}{ }^{3}}{\left(\rho_{s} / \rho-1\right) g} G\left(\frac{\tau_{c}}{\tau}\right)
$$

ここに， $\tau_{c}$ : 限界掃流力であり， $\varphi$ および $G\left(\tau_{c} / \tau\right)$ は それぞれ次式で与えられる。

$$
\begin{aligned}
& \varphi= \begin{cases}0.62\left(\frac{1}{40 n}\right)^{3.5} & : n<0.025 \\
0.62 & : n \geqq 0.025\end{cases} \\
& G\left(\frac{\tau_{c}}{\tau}\right)=\frac{1}{2.517}\left\{\frac{1}{2} e^{-1}+\int_{2\left(2 \frac{\tau_{c}}{\tau}-1\right)}^{\infty} e^{-t^{2} / 2} d t\right\}
\end{aligned}
$$

限界掃流力 $\tau_{c}$ については岩垣 ${ }^{4)}$ によれば次のように 表現されることが知られている.

$$
\tau_{c}=\psi\left(\frac{U_{* d}}{\nu}\right) \cdot\left(\rho_{s}-\rho\right) g d
$$

ここに, $\psi$ は $R_{e *}=U_{*} d / \nu$ の関数であるが, $R_{e *}$ が大 きい領域 $\left(R_{e *}>50\right)$ では約 0.05 の一定值をとる. 一 般に河川ではこの領域にはいるので以後定数として考察 をすすめる. 河床せん断力 $\tau$ と摩擦速度 $U_{*}$ はそれぞ れ式 (13)，(14）によって与えることができる.

以上の考察を子まえて河床変動を表わす式 (17) の変 形を行う。まず, 式（18）を式（17）に代入すると次式 を得る.

$$
\begin{aligned}
\frac{\partial \eta}{\partial t} & +\frac{1}{1-\lambda} \frac{\left|\hat{V}_{s r}\right|}{\left|V_{s}\right|} \frac{\partial q_{\theta}}{\partial R}+\frac{1}{1-\lambda} q_{\theta} \frac{\partial}{\partial R} \frac{\left|\hat{V}_{s r}\right|}{\left|V_{s}\right|} \\
& +\frac{1}{1-\lambda} \frac{1}{R} \frac{\left|\hat{V}_{s r}\right|}{\left|V_{s}\right|} q_{\theta}=0
\end{aligned}
$$

上式の各項を

$$
\begin{aligned}
\frac{\partial q_{\theta}}{\partial R}= & \frac{G_{s}}{\left(\rho_{s} / \rho-1\right) g} U_{*}{ }^{3} H^{-1}\left(\frac{H}{R}-\frac{1}{6} \frac{\partial H}{\partial R}\right) \\
G_{s}= & \frac{8}{2.517} e^{-2\left(2 \frac{\tau_{c}}{\tau}-1\right)^{2}} \cdot \frac{\tau_{c}}{\tau}+3 G\left(\frac{\tau_{c}}{\tau}\right) \\
\frac{\partial}{\partial R} \frac{\left|\hat{V}_{s r}\right|}{\left|V_{s}\right|}= & \left(\frac{H}{H_{a}}\right)^{1 / 6} \cdot\left\{-f_{0} \frac{U_{a}}{A_{r} U_{* a}} \frac{H}{R} \frac{1}{\kappa} F(0)\right. \\
& \left.\cdot\left(\frac{7}{6} H^{-1} \frac{\partial H}{\partial R}-\frac{1}{R}+\frac{1}{f_{0}} \frac{d f_{0}}{d R}\right)\right\} \\
& -\frac{\frac{1}{6} H^{-1} \frac{\partial \eta}{\partial R} \frac{\partial H}{\partial R}+\frac{\partial^{2} \eta}{\partial R^{2}}-\frac{1}{R} \frac{\partial \eta}{\partial R}}{\sqrt{\frac{3 C_{D} \mu}{4\left(H \mu \frac{C_{L}}{C_{D}}\right)}} \frac{\lambda_{0} A_{r} \frac{R}{R_{0}} U_{* a}}{\sqrt{\left(\rho_{s} / \rho-1\right) g d}}}
\end{aligned}
$$

などに注意して変形し, 整理すると次のように表わされ る.

$$
(1-\lambda)\left(\frac{H}{H_{a}}\right)^{1 / 3}\left(\frac{3}{4} \frac{\mu C_{D}}{1+\mu C_{L} / C_{D}}\right)^{1 / 2}
$$




$$
\begin{aligned}
& \cdot \frac{A_{r} \lambda_{0} U_{* a}}{\left\{\left(\rho_{s} / \rho-1\right) g d\right\}^{1 / 2}} \frac{1}{q_{\theta a}}\left(\frac{R}{R_{0}}\right)^{-2} \frac{\partial \eta}{\partial t} \\
& +A f_{0} \frac{H}{R}\left(\frac{1}{R} \frac{G_{s}}{G}+\frac{1}{f_{0}} \frac{d f_{0}}{d R}\right) \\
& +\left[A f_{0} \frac{1}{R_{0}}\left(\frac{7}{6}-\frac{1}{6} \frac{G_{s}}{G}\right)\right. \\
& \left.-\left\{\frac{1}{R} \frac{G_{s}}{G}+\frac{1}{6} \frac{1}{H}\left(1-\frac{G_{s}}{G}\right) \frac{\partial \eta}{\partial R}\right\}\right] \frac{\partial \eta}{\partial R} \\
& -\frac{\partial^{2} \eta}{\partial R^{2}}=0
\end{aligned}
$$

ここに，

$$
\begin{aligned}
A= & -\left(\frac{3}{4} \frac{\mu C_{D}}{1+\mu C_{L} / C_{D}}\right)^{1 / 2} \frac{\lambda_{0} U_{* a}}{\left\{\left(\rho_{s} / \rho-1\right) g d\right\}^{1 / 2}} \\
& \cdot \frac{1}{\kappa} \frac{U_{a}}{U_{* a}}\left\{F_{A}(0)-\frac{1}{\kappa} \frac{U_{* a}}{U_{a}} F_{B}(0)\right\} \\
q_{\theta a}= & \varphi \frac{U_{* a}{ }^{3}}{\left(\rho_{s} / \rho-1\right) g} G
\end{aligned}
$$

であり, $A$ は無次元のパラメーター, $q_{\theta a}$ は断面平均の 単位幅当りの流砂量を表わす. $A$ の值は具体的にどの 程度かを見積ってみる. $\mu=0.43, C_{D}=0.4, C_{L} / C_{D}=$ $0.85^{2)}, \kappa=0.4$ ，および $\lambda_{0}=0.592$ を用い， $F_{A}(0)=-$ $4.167, F_{B}(0)=-2.640$ を考慮して, たとえば代表的に

$$
\frac{U_{a}}{U_{* a}}=10, \frac{U_{* a}}{\left\{\left(\rho_{s} / \rho-1\right) g d\right\}^{1 / 2}}=0.5
$$

とすれば $A$ の值は約 8 となる. 式 (20) のままでは現 象を支配しているパラメーターが明白でないので, 次に 式 (20) の無次元化を行う. 一般の河川のように掃流力 が大きい場合には $G$ は一定と見なしうる，また，曲率 半径が大きい水路の場合は $R_{0}$ は水路中心の曲率半径 $R_{c}$ によって置き換えることができる．座標の原点を水 路中心に移すような座標変換を行うと, 無次元化された 河床変動を表わす基礎方程式は次のように書き表わされ る。

$$
\begin{aligned}
& \frac{\partial\left(\frac{\eta}{H_{a}}\right)}{\partial T}=-\left(1+\frac{\eta}{H_{a}}\right)^{-1 / 3} A\left(1+\frac{\eta}{H_{a}}\right) W \\
& \cdot\left(f_{0} \frac{3 W}{1+W \zeta}+\frac{\partial f_{0}}{\partial \zeta}\right)(1+W \zeta)^{2} \\
& \quad-\left(1+\frac{\eta}{H_{a}}\right)^{-1 / 3}\left\{f_{0} A W-\frac{2}{3}-\frac{3 W}{1+W \zeta}\right. \\
& \left.+\frac{1}{3}\left(1+\frac{\eta}{H_{a}}\right)^{-1} \frac{\partial\left(\frac{\eta}{H_{a}}\right)}{\partial \zeta}\right\}(1+W \zeta)^{2} \\
& \quad \frac{\partial\left(\frac{\eta}{H_{a}}\right)}{\partial \zeta}+\left(1+\frac{\eta}{H_{a}}\right)^{-1 / 3}(1+W \zeta)^{2} \frac{\partial^{2}\left(\frac{\eta}{H_{a}}\right)}{\partial \zeta^{2}}
\end{aligned}
$$

$こ こ に ，$

$$
T=\frac{1}{(1-\lambda)\left(\frac{3}{4} \frac{C_{D \mu}}{1+\mu C_{L} / C_{D}}\right)^{1 / 2} \frac{\lambda_{0} A_{r} U_{* a}}{\left\{\left(\rho_{s} / \rho-1\right) g d\right\}^{1 / 2}}}
$$

$$
\begin{gathered}
\cdot \frac{q_{\theta a} t}{B^{2}} \\
\zeta=\frac{b}{B}, W=\frac{B}{R_{c}}
\end{gathered}
$$

$b:$ 水路中心を原点とする横断方向の座標

$B:$ 水路幅

である.この結果から, 水路幅 $B$ が大きいと弯曲水路 の河床変動が安定勾配に達する時間が長くなるが, 流砂 量 $q_{\theta a}$ は $U_{* a}{ }^{2} /\left(\rho_{s} / \rho-1\right) g d$ に比例すると考えられる から, 掃流力 $U_{* a} /\left\{\left(\rho_{s} / \rho-1\right) g d\right\}^{1 / 2}$ が大きいと早く安 定な横断河床形状に達することになる. また無次元時間 $T$ の経過に伴う横断河床形状の変化は水路幅と水路中 心の曲率半径との比 $B / R_{c}$ と無次元パラメーター $A$ に よって支配される.このことは横断安定河床形状を決定 しているパラメーターと同一であり ${ }^{2)}$, 横断河床形状の 時間的変化も $A$ と $B / R_{c}$ を用いて整理しうることを示 している.

\section{（3） 河床変動を表わす式の数値解}

基礎方程式 式 (21) は非線型であるので解析解を得る ことは困難であり, 数值的に解かねばならない.したが って, $\eta / H_{a}$ の数值計算は $B / R_{c}, A$ および $f_{0}$ の組み 合わせに対して式 (21) を解くことになる.

計算方法は差分法を用い, 次のような表示を行う. 無 次元時間 $T$ に関する偏微分湔進差分,

$$
\frac{\partial\left(\frac{\eta}{H_{a}}\right)}{\partial T}=\frac{\left(\frac{\eta}{H_{a}}\right)_{i \cdot j+1}-\left(\frac{\eta}{H_{a}}\right)_{i \cdot j}}{\Delta T}
$$

を用い， $\zeta$ に関する偏微分は中央差分，

$$
\begin{aligned}
& \frac{\partial\left(\frac{\eta}{H_{a}}\right)}{\partial \zeta}=\frac{\left(\frac{\eta}{H_{a}}\right)_{i+1, j}-\left(\frac{\eta}{H_{a}}\right)_{i-1, j}}{2 \Delta \zeta} \\
& \frac{\partial^{2}\left(\frac{\eta}{H_{a}}\right)}{\partial \zeta^{2}}=\frac{\left(\frac{\eta}{H_{a}}\right)_{i+1, j}-2\left(\frac{\eta}{H_{a}}\right)_{i, j}+\left(\frac{\eta}{H_{a}}\right)_{i-1, j}}{(\Delta \zeta)^{2}}
\end{aligned}
$$

を用いる.ここに, $\Delta T$ : 無次元時間 $T$ の増分, $\Delta \zeta:$ 横 断方向の無次元距離 $\zeta$ の増分, $i, j$ : 距離および時間に 関する Subscripts である.上記の表現を式 (21) に代 入すると差分表示式が得られる.

側壁の影響で横断方向の二次流が減少する程度を示す $f_{0}$ は前に述べたように横断方向の大部分の領域 で強制 渦型, $R / R_{c}$ となるが, 側壁近傍では水深や側壁の粗さ などによって変化し，その分布形については明らかでな い. また, 河床が変動する場合については研究がなされ おらず, 本数值計算では, 内壁, 外壁からそれぞれ水路 幅の 1 割離れた所までを側壁の影響域と考え, その区域 で壁では 0 , 水路中央部との接続点では $R / R_{c}$ となるよ うに $f_{0}$ を二次曲線で仮定した. $f_{0}$ を横断方向の全領 域で強制渦形分布とせずいま述べたような分布形とした 
時に河床形状におよぼす影響を図一2に示す．数值計算 に際しては $\Delta T=0.0001, \Delta \zeta=0.025$ とした。図一3は 以上の考察により $f_{0}$ の分布形を与えたので， $f_{0}$ はパ ラメーターから除き, 弯曲水路の河床変化がパラメータ 一，B/Rc と $A$ によって決定されることが明らかとな

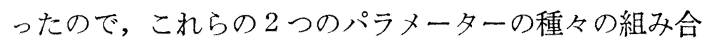

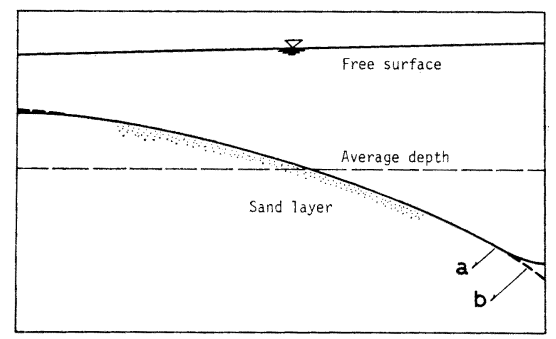

(a) $f_{0}=R / R_{c}$ (水路中央部)，

$f_{0}=$ 二次放物線（側壁近傍）とした場合

(b) $f=R / R_{c}$ とした場合

図一2 $\boldsymbol{f}$ の分布形の仮定が河床形状の計算におよぼす影響

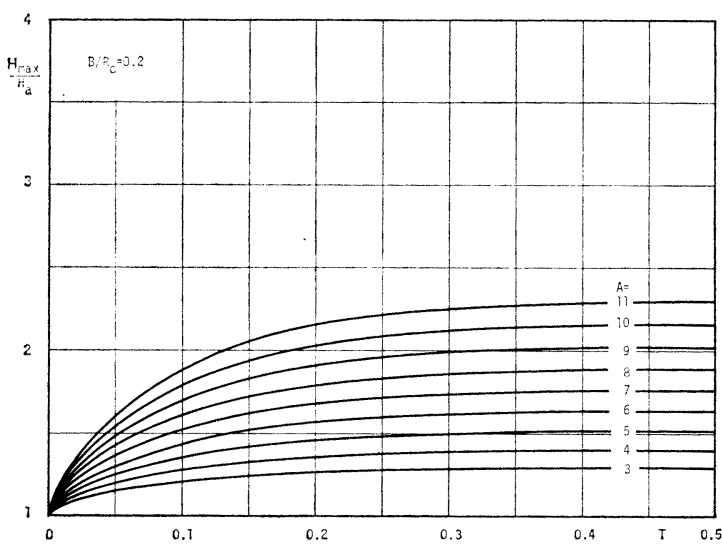

(a)

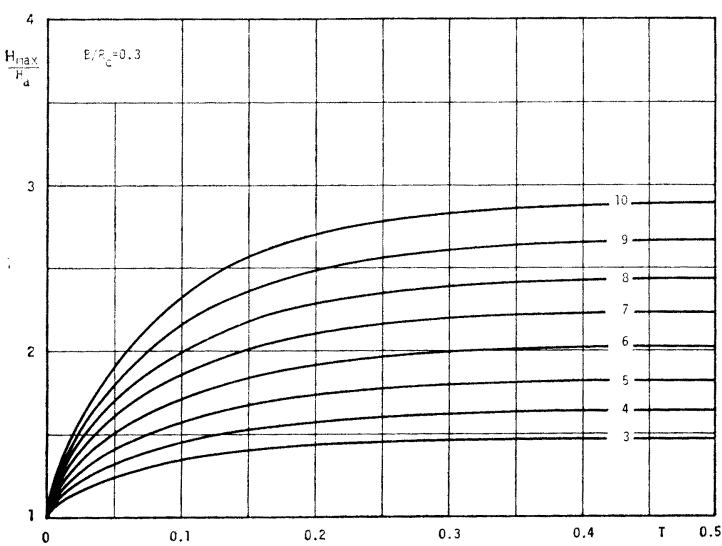

(c)
わせについて現実によく起こる範囲について式 (21) を 数值的に解き, 外岸で生ずる最大洗掘深の時間変化を 示したものである.計算結果 は縦軸を無次元最大水深 $H_{\max } / H_{a}$ にとり横軸を無次元時間 $T$ として整理され ている.これらの計算結果から $B / R_{c}$ が大きいほど, 掃 流力の目安である $A$ の值が大きいほど最大洗掘樑が大 きくなることが知られ，また時間的には初期に急激に掘 れ時間が経過するにつれて一定值に近づき，いわゆる安 定河床に漸近していくことがわかる. なお，この数值計 算によって求められた最終的な最大洗掘深を筆者の一人 が解析的に得た最大洗掘深 2 上比較すると前者が後者よ りもやや小さ目の值を与えている．これは先にも述べた ごとく前者では式 (15) のように二次流の横断方向の分 布形 $f_{0}$ を側壁付近で補正したためであって，後者にお いては解析解を得るためにこの補正を行わず，したがっ て理論值の方が実験值よりもやや大きな值を与えていた のに比してより実測值に近い值を与える。

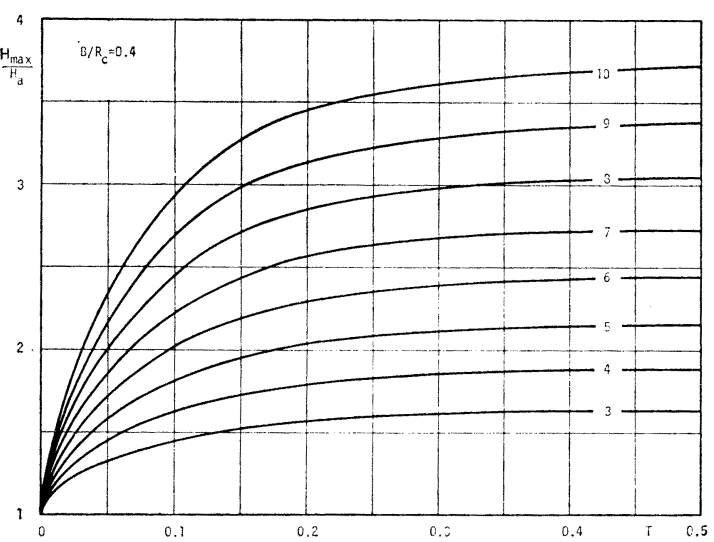

(b)

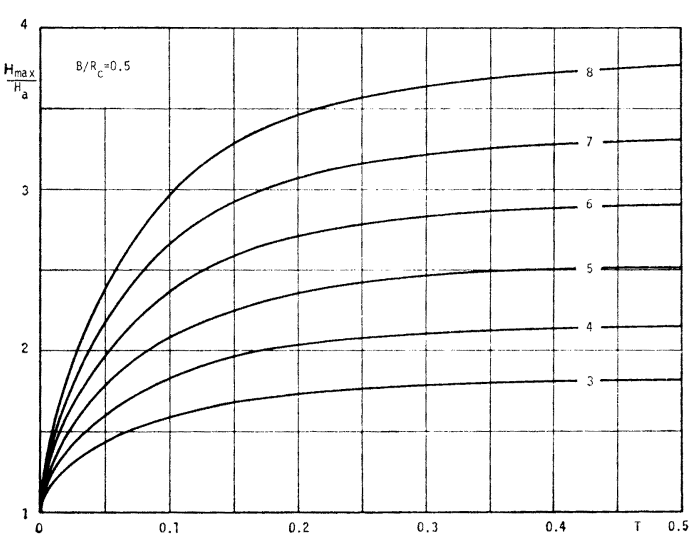

(d) 


\section{3. 弯曲水路における実験}

\section{(1) 実験の概要}

実験は中心曲率半径 $R_{c}=450 \mathrm{~cm}$, 水路幅 $100 \mathrm{~cm}$, 弯 曲角 $306^{\circ}$ を持つ長方形断面水路で行わ机た. 水路は鉄 板製であるが，底にモルタルを張り，流下方向の河床勾 配が水路中心で正確に $1 / 500$ になるように修正を施して ある(図一4)。

まず実験は河床の変形前の流れの特性を把握するため にモルタルの上に移動床の実験で用いられる砂を張りつ けた固定床で行われ, 速度分布, 河床上のせん断力分布 を測定した.

移動床の実験では表一1 に示される物性を持つ砂を水 路床に高さ $10 \mathrm{~cm}$, 勾配 $1 / 500$ になるように敷きつめ た. 流砂が Tail tank に流れこまないように高さ 10 $\mathrm{cm}$ の砂止めをおいた. 実験の手順は流れが一定の流量 に達した時を実験開始点とし， $180^{\circ}$ 弯曲した点（以下 観測点とよぶ）で河床変化を所定の時間間隔ごとに測 定した。流量は Head tank に取り付けられた矩形刃型 堰によって測られた. 実験は河床形状が最終状態に達し たと判断される時間まで続けられ, その後ポンプを停止

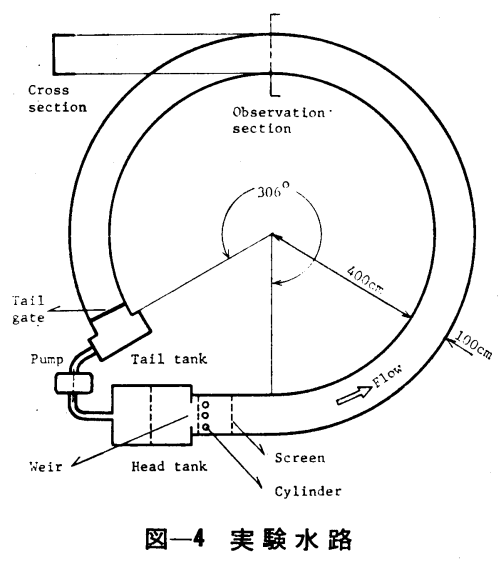

表一1 実験に用いられた砂の特性

\begin{tabular}{|c|c|c|c|}
\hline $\begin{array}{l}\text { 密 } \\
\rho_{s}\left(\mathrm{~g} / \mathrm{cm}^{3}\right)\end{array}$ & $\begin{array}{l}\text { 中央 粒 径 } \\
d_{50}(\mathrm{~mm})\end{array}$ & $\underset{\lambda(\%)}{\text { 空 }}$ & $\begin{array}{c}\text { 均等係数 } \\
d_{60} / d_{10}\end{array}$ \\
\hline 2.65 & 0.9 & 40 & 1.4 \\
\hline
\end{tabular}

表一2 実験条件

\begin{tabular}{|c|c|c|c|c|c|c|c|}
\hline Run & $\begin{array}{c}\text { 流 }^{\mathbf{9}^{\text {量 }}} \\
(l / \mathrm{sec}) \\
\end{array}$ & $\begin{array}{c}\text { 平均水深 } \\
H_{a} \\
(\mathrm{~cm})\end{array}$ & $\begin{array}{c}\text { 平均梳速 } \\
U_{a} \\
(\mathrm{~cm} / \mathrm{sec})\end{array}$ & $\mid \begin{array}{c}\text { 平 均藦擦速度 } \\
U_{* a} \\
(\mathrm{~cm} / \mathrm{sec})\end{array}$ & $\begin{array}{l}\text { 水路床 } \\
\text { 勾 }{ }_{i_{\theta}}{ }^{\text {配 }}\end{array}$ & ${\stackrel{\text { P゙ }}{F_{r}^{*}}}^{\text {数 }}$ & $\stackrel{\sim}{\sim} \underset{R_{e}}{\text { 数 }}$ \\
\hline F 1 & 20 & 5.0 & 40.0 & 3.14 & $1 / 500$ & 0.56 & $1.95 \times 10^{4}$ \\
\hline F 2 & 25 & 5.5 & 45.5 & 3.28 & $1 / 500$ & 0.63 & $2.54 \times 10^{4}$ \\
\hline F 3 & 30 & 6.3 & 47.6 & 3.51 & $1 / 500$ & 0.61 & $3.02 \times 10^{4}$ \\
\hline M 1 & 25 & 5.5 & 45.5 & 3.28 & $1 / 500$ & 0.63 & $2.54 \times 10^{4}$ \\
\hline M 2 & 30 & 6.3 & 47.6 & 3.51 & $1 / 500$ & 0.61 & $3.02 \times 10^{4}$ \\
\hline
\end{tabular}

し砂面測定器によって水路の全面にわたって河床形状を 測定した. 最後に小さな砂粒子ほど内岸側へ運ばれやす いことのために生ずるふるい分け現象を見るために観測 点で内壁, 水路中心, 外壁の三点で砂を採取し, 粒度分 布, 比重を調べた. これらの各実験条件は表一2 に示さ れている.

\section{（2）固定床での実験}

流れの速度および流向は上端に分度器のついたピトー 管と，細い木綿糸をピト一管の総圧口と同じ高さで流向 を測れるように設置した装置を用いて測定された。すな わち, 糸の向く方向にピト一管を合わせ, 上端の分度器 で流向を測り, 横断方向の二次流の成分はピトー管で得 られた流速に水路の接線方向からの偏倚角の正弦を乗じ て求められ, またこの偏倚角は小さいので余弦はほとん ど 1 と考えてよく，したがって主流成分は測定された流 速と同じとした. 図一5 は測定断面 $\left(\theta=180^{\circ}\right)$ で深さ方 向に平均された流速 $U_{m}$ を断面での平均流速 $U_{a}$ で無 次元化した分布形を示したものであり, 式 (12) で表現 される強制渦型の速度分布と比較したものである. 内壁 近くでは強制渦分布よりやや遅め, 外壁近くでは速めの 傾向を示しているが，全体としては強制渦の速度分布で 横断方向の流速分布を近似しうるものと思われる.

図一6 は各横断方向の点での主流流速の測定值と式 (7) で示される二次流の速度分布を得る際に用いられた 速度欠損則,

$$
\frac{U_{\theta}}{U_{a}}=\frac{R}{R_{c}}\left\{1+\frac{U_{* a}}{\kappa U_{a}}\left(\ln \frac{Z}{H}+1\right)\right\}
$$

を比較したものである. 実験值は $20,25,30 \mathrm{lit} / \mathrm{sec} の$ 3 ケースについて行われたのでこれらの実験值がプロッ トされている.実線は $25 \mathrm{lit} / \mathrm{sec}$ の場合の計算值である が, 3 ケースとも $U_{* a} / U_{a}=1 / 14 \sim 1 / 12$ であってほぼ同 じ值を示しており, この線で他の 2 つの場合も表現する ことができる.すべての場合について実験值は次のよう な特徽を有している. 内壁近傍では水面近くで流速が小 さくなり, 逆に外壁近傍では底面近くで流速が大きくな

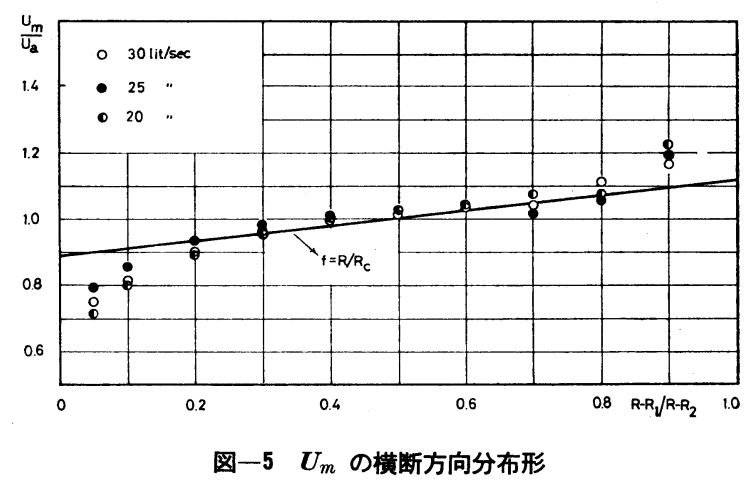



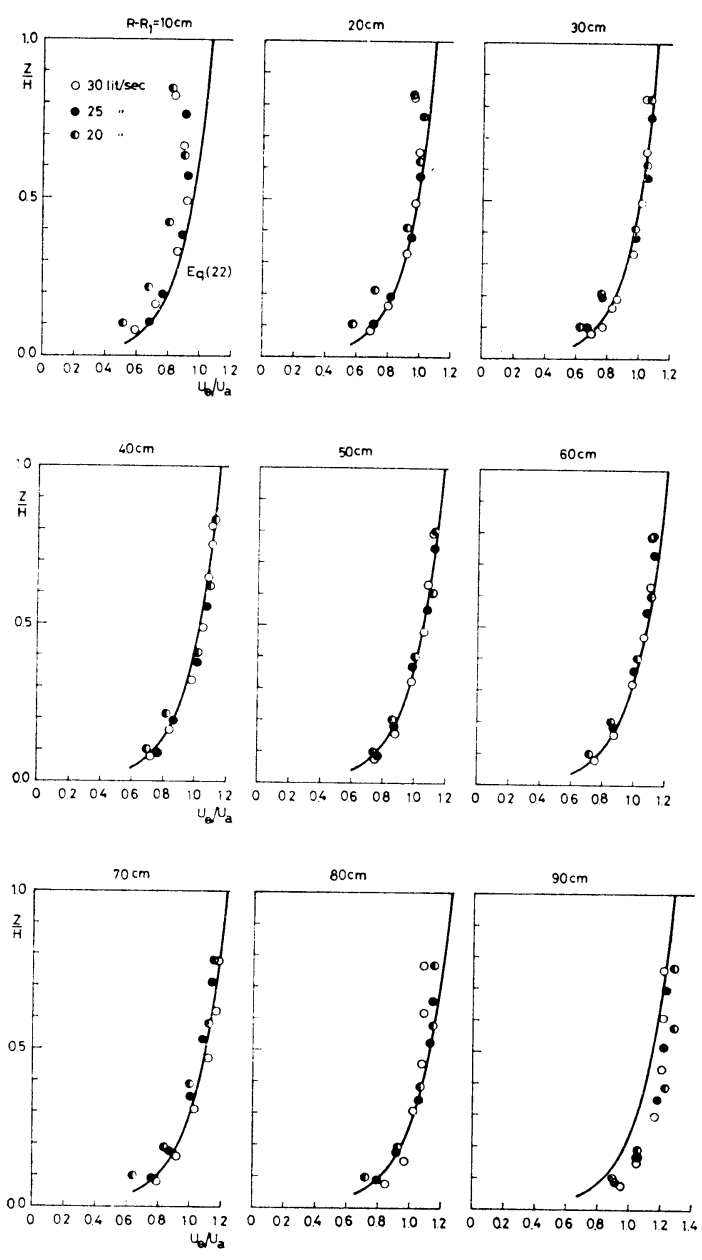

図一6 主流の断面内速度分布

っている．これは内壁付近では底層の小さな運動量を持 つ流体が二次流によって表層へ持ちこまれてその部分の 流速を小さくし, 逆に外壁付近では表層の大きな運動量 が底層へ持ちこまれて流速を増大させているためであ る.このように側壁近傍では二次流による運動量交換の 影響が現われ，上に示された式とは若干異なった速度分 布形を示す.けれどもこの側壁近傍を除く領域では上式 と実験值はよく一致し，深さ方向には $\kappa=0.4$ とした 対数則, 横断方向には強制渦型の分布形によって 流れの速度分布形をよく表わしらることを示して いる.

図-7 は横断方向の二次流の速度成分について 示したものであって，同時に式 (7) $(\kappa=0.4)$ と の比較がなされている. 側壁の近傍, すなわち内 壁より $10 \mathrm{~cm}, 20 \mathrm{~cm}$ ，および $80 \mathrm{~cm} ， 90 \mathrm{~cm}$ の 外壁近くでは側壁の存在によって深さ方向の二次 流成分が卓越してくるために実験值は計算值より もかなり小さくなっている. 式 (7) はその誘導の
過程で広幅水路であることが仮定され，側壁の効果が無 視されているのでこれらの不一致は当然であろう。ま た，水路の中央付近においても実験值が理論值よりもや や小さめである.これは式 (7) の誘導に際して,レイ， ルズ方程式の非線型項（加速度項）を無視したことと, 式 (7) の誘導に際して用いられた渦動粘性係数の值が実 際よりも小さいことが考えられるが，この非線型效果に

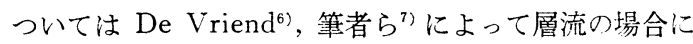
ついて有限幅の弯曲水路について理論的に見積られ，二 次流の大きさを小さくする効果のあることが明らかにさ れている. 式 (7) の誘導に際しては水路幅が非常に大き いとしこの非線型の加速度項を無視しているので, この 効果が見積られていず，したがって理論值の方がやや大 き目に計算されたものと思われる．そこでこの非線型効 果は小さいことを利用して，この加速度項を抵坑の増大 としてとらえ，摩擦力の項に含めて考えるこよにする と，実用上は $\kappa$ を増加させることによってその解決を

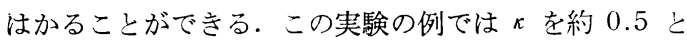
とれば 理論值と実験值の適合性はよいようであるが， の増大量は水路の横断形状, 水路幅と水深の比などの関 数であると思われ，これらの関数形については明らかで 汭なく今後の課題であろう。

底面のせん断力分布と主流の速度分布との対応を調べ るために外径 $6 \mathrm{~mm}$ のプレストン管を用いて河床面のせ ん断力を測定した. 底面近くの流向に合わせるために総 圧管のすぐ上に長さ $7 \sim 8 \mathrm{~cm}$ の木綿采を取り付け，そ の方向に管口を向けた. 分布の変化の状況を知るために
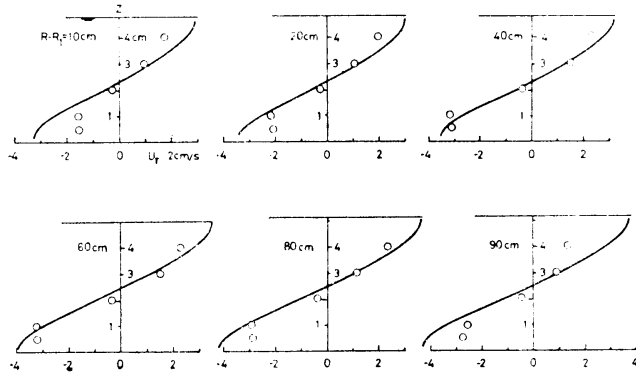

図-7（a）二次流の速度分布形 $(Q=20 \mathrm{lit} / \mathrm{s})$
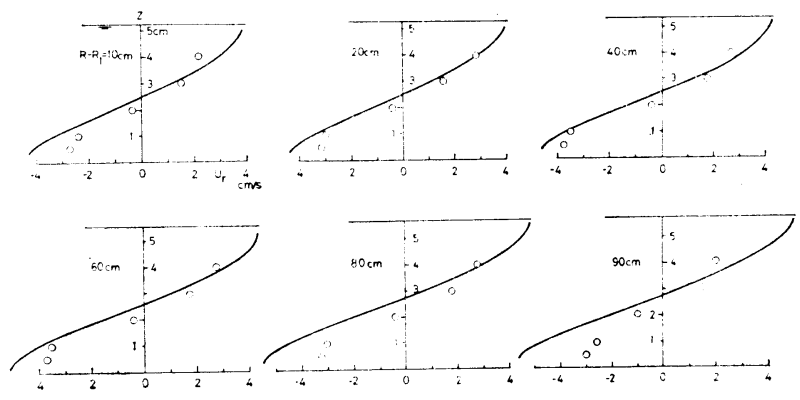

図一7 (b) 二次流の速度分布形 $(Q=25 \mathrm{lit} / \mathrm{s})$ 

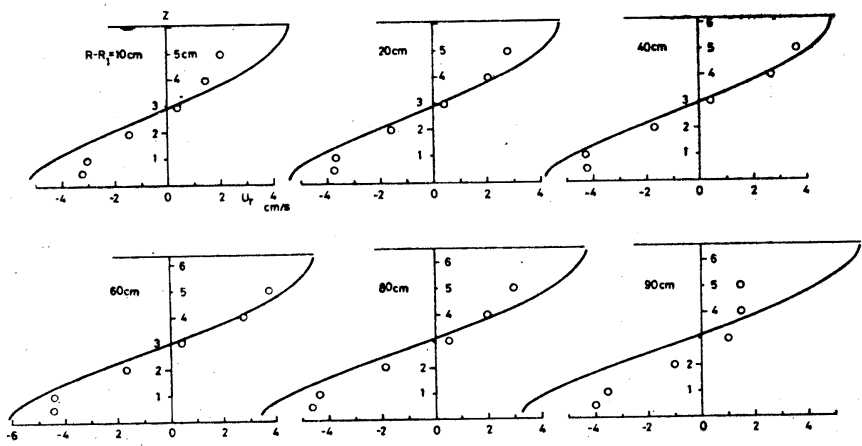

図-7 (c) 二次流の速度分布形 $(Q=30 \mathrm{lit} / \mathrm{s})$

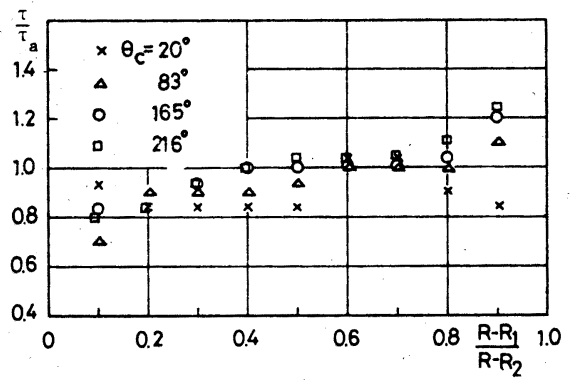

図一8 底面せん断力の変化

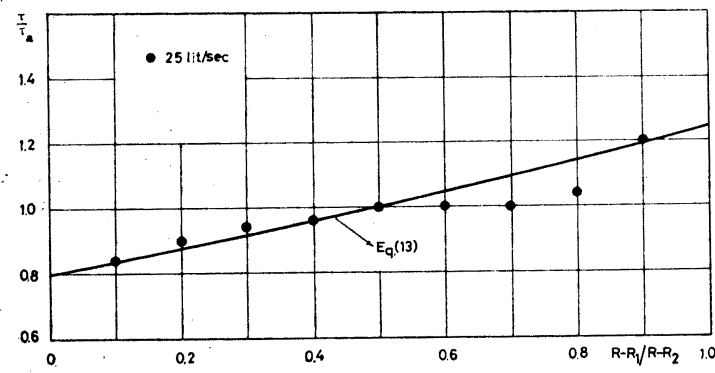

図一9底面せん断力の分布 $\left(\theta_{c}=180^{\circ}\right)$

図一8に示すように流向方向の各断面でせん断力の測定 を行った．流下するに従い，最大のせん断力は外壁近く に移動していく状況が示されている. 図一9 は観測点 $\left(\theta_{c}=180^{\circ}\right)$ で実測されたせん断力分布と式 (13) との比 較を示している. 内壁功 $60 \sim 80 \mathrm{~cm}$ 付近で実測值は 理論值よりもやや小さめになっているが，先に示された ように実測された主流の速度分布もこの付近で強制渦形 の分布よりも小さくなっており，主流の速度と底面せん 断力が直接対応していることをうかがわせている.けれ どもせん断力分布は式 (13) によって㧍㧍む㸚良好に表 現しうるといってよいであろう。

\section{（3）移動床での実験}

移動床での実験は 25, $30 \mathrm{lit} / \mathrm{sec}$ のケースについて行 われた. 一定流量を流すと通水初期には流下方向に一様 に外壁沿いで洗掘と内壁沿いで堆積がおこるが, 時間が

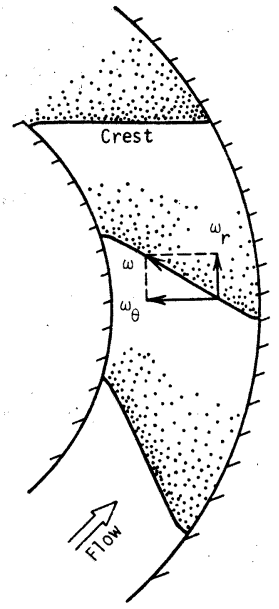

図一10 河床波の概念図

経過するにつれて二次元的な砂堆が生じ，次第に増幅さ れてゆく.この砂堆は広幅水路であるにもかかわらず， 直線水路のそれとは異なり, 図一10に示されているよ うに峰が内壁から外壁まで切れることなく続き，しかも この砂堆を河床波と考えると内壁洽いの方が常に位相が 進んでいる.このような形状の砂堆が生ずる理由は, 直 線水路では縦渦の発生の仕方が極めて不安定で渦度べク トルの方向が一義的に定まらず，したがって河床面が複 雑な三次元的な様相を示すのに対し, 弯曲水路では縦渦 (ここでは二次流) の方向が安定で, 主流と二次流の作 る渦度ベクトルの方向が常に 図一10 に示される方向に 向いているためであると思われる. この事実は逆に直線 水路の河床波を取り扱ううえで流れの三次元性を考慮し なければならないことを示唆しているともいえる.この

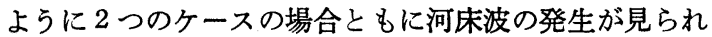
るが, 時間の経過に伴い, 外壁での洗掘および内壁での 堆積は次第に大きくなっていく.

図一11 は “観測点” で測定された河床変化の様子と式 （21）を数值積分することによって得られた解の比較を 行ったものである. 計算は 表一2 中の Run M 1, M 2 について行われ, 式 (21) を解くに際して必要な水理 量, 河床構成材料の条件は 表一1，2 に示されている. また, このとき粗度俰数 $n$ の值は表一2 を用いて求 めることができるが M 1 に対して $n=0.014, \mathrm{M} 2$ に 対して $n=0.015$ であった.ここで測定值は河床波の通 過による影響を取り除くために峰と谷の部分の平均值を 用いてある. $25 \mathrm{lit} / \mathrm{sec}$ の場合には水路の中央付近でや や対応が悪いが，その他の部分および $30 \mathrm{lit} / \mathrm{sec}$ の場合 については河床の形状および洗掘, 堆積の過程をよく表 わしている.

図一12 は外壁付近の河床変化に注目し， $R-R_{1}=95$ $\mathrm{cm}$ （すなわち外壁より $5 \mathrm{~cm}$ ）における河床変化の様子 


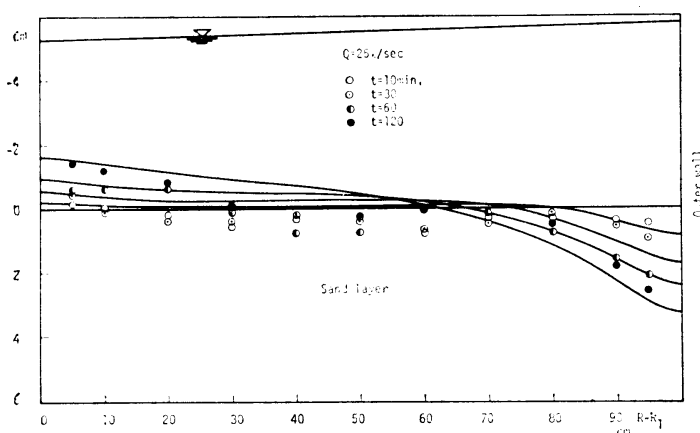

図一11 (a) 横断方向の河床変化（実線法計算值）

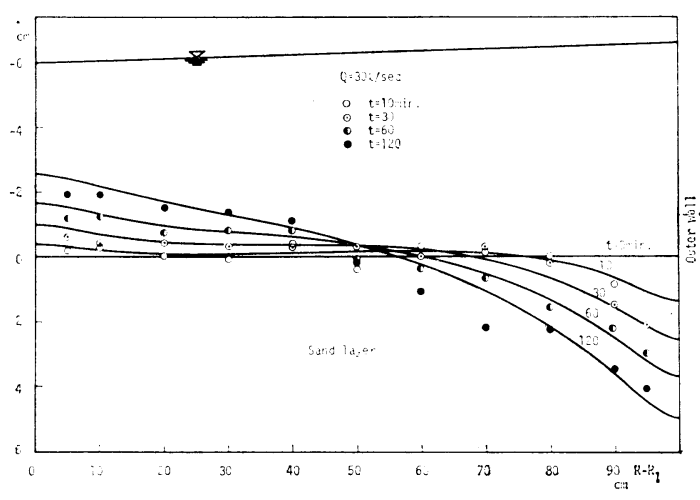

図-11 (b) 横断方向の河床変化（実線は計算值）

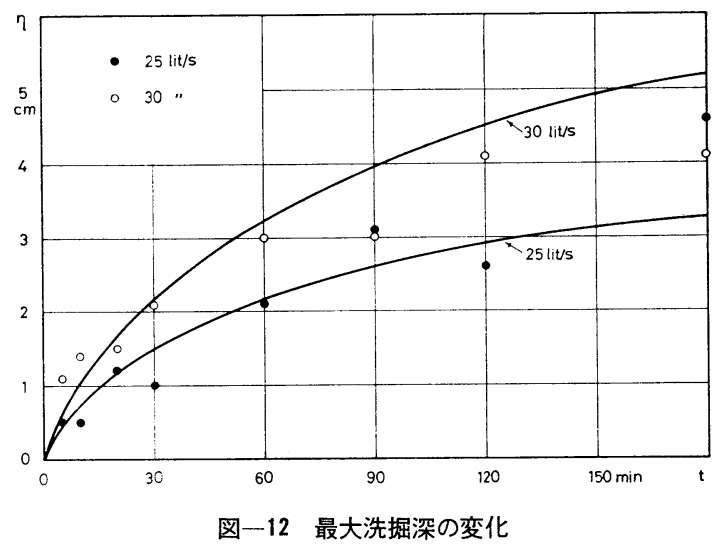

を示したものである. 実線は式（21）を数值計算するこ とによって求められた理論值を示し，丸印はそれぞれの 実験条件に対応する実験值を示している.

流量 $30 \mathrm{l} / \mathrm{sec}$ を流し, 河床形が最終状態に達した後, 内壁付近, 水路中心, 外壁付近の 3 点で水路床の砂を採 取しおのおのの粒度分布と比重を調べた。図一13 はそ の 3 点で採取した試料の粒度加積曲線を示したものであ る.内壁付近での加積曲線は粒径の小さい方へ移行し, 外壁近くでは粒径の大きい方へ移行している. また, 水 路中心の砂の粒度分布は通水前に敷きつめた砂の粒度分

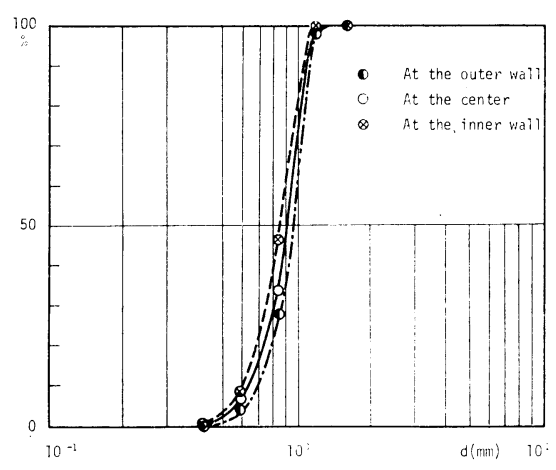

図一13 ふるい分け現象

布とほとんど一致している，目視によっても二次流の上 昇部にあたる内壁のごとく近傍では砂に含まれている小 さな雲母分が堆積し, 内壁に平行に黒い帯状となって見 えた.このような弯曲水路におけるふるい分けの現象は 水流によって移動しやすい粒径の小さな砂が外壁側から 内壁側へ運ばれたことを示し, 弯曲水路の河床変化が二 次流によって支配されていることの一つの根拠を与える ものとして注目される. なお， 3 点で採取した試料の比 重に関しては差異はほとんど見られなかった。

\section{4. 結論}

流下方向に一様な弯曲水路において河床が安定形状に 達するまでの河床変化の理論的な取り扱いを行った。ま た, 弯曲水路において固定床と移動床の実験を行い, 次 の諸点が明らかとなった。

（1） 主流の横断方向の速度分布は強制渦型によって 近似することができ，深さ方向の分布については対数則 によってよく表わすことができる. また, 二次流の速度 分布については線型理論から導かれた式 (7) は実験值よ りもやや大き目の值を与える.これは非線型項を無視し たためであると思われるが，水路中央部付近ではカルマ ンの定数 $\kappa$ を 0.4 よりも大きくとることによってこの 䛊差を補正することができる.

（2）流砂の移動方向の変化を考慮して弯曲水路の横 断方向の河床変化を表わす式を導き, 得られた方程式を 差分法によって数值計算を行った. その結果を実験值と 比較し,このモデルで河床変化の過程をよく表現しらる ことを明らかにした．また，この方程式を無次元化して 検討することによってこのような河床変化の現象が 3 個 のパラメーター, $B / R_{c}, A, T$ によって決定されている ことを示し，これらの值を用いて計算結果の整理を行っ た.

（3）移動床における実験においては二次元的な砂堆 の発生が見られ, その形状は二次流の存在と密接な関連 
性があることが推察された。

(4) 弯曲水路では横断方向にふるい分け現象が観察 され，外壁側では粒径が大きく，内壁側では小さくなる 傾向が見られた。

\section{5.あとがき}

ここで得られた河床変化の理論は実験室ではその妥当 性がほぼ証明されたが，実際河川でも成立することを確 かめたいと思っている．目下資料を収集中であり，この 点に関しては別の機会に発表する予定である.最後に実 験に際し，多大の援助を提供された佐藤郁太郎技官に謝 意を表わします。

記法

$A:$ 無次元パラメーター

$A_{r}:$ 定数 $(=8.5)$

$B:$ 水路幅

$b:$ 水路の中心線を原点とする横断方向の座標 $\left(=R-R_{c}\right)$

$C_{D}:$ 砂粒子の抗力係数 $(=0.4)$

$C_{f}:$ 抵抗你数

$C_{L}$ : 揚力係数 $\left(C_{L} / C_{D}=0.85\right)$

$d:$ 砂粒子の粒径

$F_{A}, F_{B}:$ 二次流の速度分布関数形

$f\left(R / R_{0}\right)$ : 主流の横断方向の速度分布形

$G\left(\tau_{c} / \tau\right)$ : 関数 (佐藤-吉川-芦田の流砂量式)

$g:$ 重力の加速度

$H:$ 水深

$i_{\theta}:$ 河床の接線方向の勾配

$k_{s}:$ 相当粗度

$n:$ マニングの粗度保数

$q_{r}, q_{\theta}: R, \Theta$ 方向への流砂量

$q_{\theta a}:$ 断面平均の $\Theta$ 方向流砂量

$R:$ 半径方向の座標

$R_{s}:$ 砂粒子の軌道の曲率半径

$R_{c}:$ 水路中心の曲率半径

$R_{1}, R_{2}$ : 水路の内岸, 外岸における曲率半径 $S:$ 河床に沿う半径方向の座標
$T:$ 無次元時間

$t:$ 実時間

$U:$ 砂粒子の高さにおける流体の速度

$U_{a}:$ 断面内の平均流速

$U_{m}$ : 半径方向の一地点における深さ方向に平均 された流速

$U_{r}:$ 流れの $R$ 方向速度成分 $\left(=-\hat{U}_{r}\right)$

$U_{* a}:$ 断面平均の摩擦速度

$U_{\theta}:$ 流速の接線方向成分

$V_{s}:$ 砂粒子の移動速度

$V_{s \theta}, \hat{V}_{s r}: V_{s} \rho \Theta, R$ 方向成分（内向き正）

$W: B / R_{c}$

$Z:$ 垂直方向の座標（上向き正）

$\zeta: b / B$

$\eta:$ 平均水深からの掘れ $\left(=H-H_{a}\right)$

$\Theta:$ 接線方向の中心角

$\kappa:$ カルマン定数

$\lambda:$ 空隙率

$\lambda_{0}:$ 遮蔽係数 $(=0.592)$

$\mu:$ 動摩擦係数 $(=0.43)$

$\xi: Z / H$

$\rho:$ 流体の密度

$\rho_{s}:$ 砂粒子の密度

$\tau:$ 河床面に㗢くせん断力

$\tau_{c}:$ 限界掃流力

$\varphi:$ 倸数 $(n$ の関数 $)$

\section{参 考 文 献}

1）村本嘉雄・坂本忠彦・吉村知司：弯曲水路の河床变動に 関卞る研究, 京都大学防災研究所年報, $11 \mathrm{~B}, 1968$.

2）池田駿介: 移動床河川の弯曲部における二次流と動的 横断平衡河床について，土木学会論文報告集， 229 号， 1974.

3）須賀堯三：開水路わえ曲部河床の安定形状（その 2), 第 10 回水理講演会講演集, 1966.

4）岩坦雄一：限界揥流力に関する基礎的研究，上木学会論 文集, 41 号, 1956.

5）佐藤清一・吉川秀夫・芦田和男：河床砂碑の掃流運搬に 関卞る研究 (1), 建設省士木研究所報告, 98 号, 1957.

6) De Vriend, H.J. : Theory of Viscous Flow in Wide Curved Open Channels, Proc. of I.A.H.R., Bangkok, 1973.

7）吉川秀夫・池田駿介：わえ曲水路に打污る二次流の数值 解, 土木学会第 18 回水理講演会講演集, 1974.

(1975.9.26 - 受付) 